\title{
The operation and production of the barramundi, Lates calcarifer, at the Good Fortune Bay (GFB) Barramundi Farm Australia
}

\author{
Ludi Parwadani Aji ${ }^{1 *}$ \\ ${ }^{1}$ Technical Implementation Unit For Marine Life Conservation, Research Centre For Oceanography, Indonesian Institute of
} Science (LIPI)

\begin{abstract}
Barramundi (Lates calcarifer) is a commercially important species in Australia and Southeast Asia. Barramundi are not difficult to accept artificial diets, resistant to disease and can grow faster in warm climates. System operation in Good Fortune Bay (GFB) Barramundi Farm in Kelso can be divided into nursery and grow-out management sections. The water source for nursery and grow-out is come from ground water with semi-recirculated system was applied. Every cage in the grow-out ponds has equipment with 4-wheel paddlewheel aeration. Aeration is eminent usually at night when the dissolve oxygen (DO) level in the ponds drop. To prevent predation and disease, each cage is covered by oyster tray lid and nursery tanks are always cleaned to remove pathogens. In the nursery, pellet is given to fish and the pellet size increase depends on the fish size, whereas, fish are feed by floating pellet for grow-out fish. Moreover, farmers measure water quality like DO every morning and also take water sample for ammonia, nitrite, nitrate analysis once a month. GFB Barramundi Farm just sells their product domestically and not import to other country since the price of barramundi from South East Asia such as Indonesia and Vietnam is much cheaper even the quality is lower than Australia product. This is because the labor and production cost in Australia is higher than South East Asia.
\end{abstract}

Keywords: barramundi, nursery, grow-out, farm

\section{INTRODUCTION}

Barramundi (Lates calcarifer) is widely distributed in fresh water and coastal throughout the Indo-west Pacific region. Barramundi or Asian sea bass is a commercially important species in Australia and southeast Asia and has recently become one of the fastest growing sectors in worldwide aquaculture with recent expansions and market development in the USA and Europe [1]. Farming of barramundi in Australia began in 1986 with 2 tons of fish coming from sea hatcheries farm. Most farmed barramundi product originates from north Queensland although it is produced in all mainland states. However, now, farmed barramundi are being produced in Western Australia, South Australia, the Northern Territory, and New South Wales [2].

Barramundi farming is expanding with continual improvements in technology. They can breed all year round and produce many offspring

\footnotetext{
*Corresponding address:

Ludi Parwadani Aji

Technical Implementation Unit For Marine Life Conservation, Research Centre For Oceanography, Indonesian Institute of Science (LIPI), Biak - Papua Barat, Indonesia. e-mail: ludi_bio@yahoo.co.id
}

under controlled conditions. Barramundi are not difficult to accept artificial diets, resistant to disease and can grow faster in warm climates [4]. The most common method for grow out barramundi is rearing in cages which built in freshwater ponds. Barramundi need to be cultured in warm temperatures (tropical area) in order to maintain commercial growth rates [5]. Moreover, Barramundi grows rapidly and is easily weaned onto pelleted diet. The species grows well in salt or fresh water, and performs well under indoor environmentally controlled recirculation systems [4]. In recent year, the number of barramundi farmers has increased which lead to the increasing of barramundi production. Production in Queensland increased from 2075 tonnes in $2005 / 2006$ to 2464 tonnes in $2007 / 2008$. In the same period, the value of those in Queensland also increased from AUD 17.2 to 18.5 million [2].

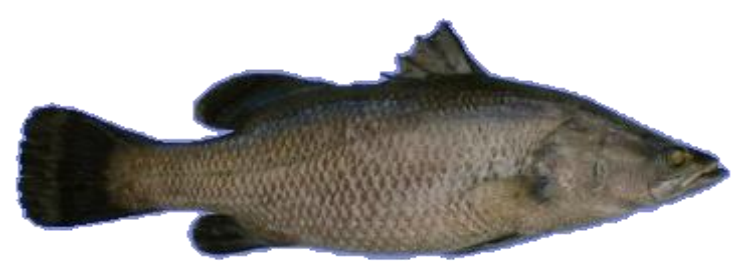

Figure 1. Barramundi fish (Lates calcarifer) [3] 
Good Fortune Bay (GFB) Barramundi Farm in Kelso, Northern Queensland has been growing for around 16 years. This is an intensive facility, semi recirculated system, has approximately 188 acre of total property, 8 hectare of aquaculture production area and has eight full time employee and some part time workers. Therefore, this essay will examine the farm design and layout that focus on operation at this farm and husbandry and production such as feed, predators / disease, water quality management. This paper also determines the marketing and provides critical analysis on obstacles that affect profitability. Hence, by knowing the management culture of Barramundi at the GFB Farm Australia can give important knowledge for aquaculture industry of Barramundi in Indonesia. Some important strategy might be copied to be applied in Indonesia.

\section{DISSCUSION}

\section{Farm design and layout}

\section{a) Water source}

The water source for nursery and growout is come from ground water. This farm is semi-recirculated system with freshwater from underground, 15\% water exchange every day and saltwater is just put in the system continually. Every day in the summer or dry climate (high temperature), water loss due to evaporation can reach up to $7 \mathrm{~mm}$ per pond. Consequently, this water loss is replaced from groundwater. There is $10 \%$ water exchange per day, as culture pond water enters the dammed settlement ponds. Moreover, the water in the systems can be stored for future use by gravity pumped back to the header. This farm use recirculation system to avoid environmental impact for surrounding area. When there is a storm in farm area, the farmer will turn off all system like aerator until the storm is over.

\section{b) Operation and practices}

System operation in GFB farm can be divided into nursery and grow-out management sections. Firstly, they purchase fingerlings that have size around $50 \mathrm{~mm}$ from a GFB hatchery (owned by same company) in Bowen city.

1) Nursery. This nursery operation used semi-recirculated system by using biofilter. The farm has 27 tanks ( 3 batches of 9 nursery tanks) which the capacity of each tank is around 5000 liters. Stocking density is 2500 fish per tank and they are kept at temperature around 260C. To reduce cannibalism, grading is conducted once a week since fish are difficult to grade in ponds and graders are designed with ratio length to width is around 10:1 which mean that $50 \mathrm{~mm}$ fish length have $5 \mathrm{~mm}$ in width. The fish that have same size is placed together in the tank before to be graded again next week. Furthermore, the survival rate from nursery to grow-out is around $80 \%$. The fingerlings are grown weekly in the nursery tank for about 5 weeks until they reach 100-120 mm before they are stocked into grow-out cages. The survival rates from nursery to grow-out are around $85-95 \%$. In addition, around 100.000 fish are placed in nursery thank and hold them in the winter until the temperature is warm enough to place in the cage.

2) Growout. The fingerlings (100-120mm) are put in cages in the pond for growout period until reach fillet size $(2 \mathrm{~kg})$. The pond (rectangular) size is approximately $40 \mathrm{~m} \mathrm{X} 30 \mathrm{~m}$ with $2 \mathrm{~m}$ in depth, that can hold around 3 million liters of water, and each pond has two cages. The cages size is $4.5 \mathrm{~m}$ in length, $3.6 \mathrm{~m}$ in width and $1.8 \mathrm{~m}$ in high and beside the cage, there is a paddlewheel aerator. Moreover, Stocking of ponds with around 100.000 fish is only done before winter when weather is warmer during summer months. Because when the temperature below than $23^{\circ} \mathrm{C}$, their immune system or metabolism will be very slow and it leads to poor growth. The fish has vaccination treatment by injecting to prevent form disease after they reach around $80 \mathrm{~mm}$ because in that size they easy to handle.

There is 7000 stocked fish in each cage which stocking density at $200 \mathrm{~kg} / \mathrm{m} 3$. Considering the pond size, this worked out to be a very high stocking density compared to stocking levels recommended in aquaculture industry standard manual with just at 4-50kg/ m3 [4]. High fish densities in confined environments are often associated with increased mortality, pathogens, reduced growth rates, increased competition for food and elevated levels of metabolites [6]. However, GFB farm have good recirculation system, aeration and always control water quality that allow high stocking density to be reared.

\section{c) Aeration}

Supplementary aeration in this farm must be provided because the stocking density of the fish in the cage is very high. Every cage in the grow-out ponds has equipment with a 4-wheel paddlewheel aeration which always move 24 hours per day. Therefore, the bill for electricity in 
this farm is huge mainly from aeration. Aeration is eminent usually at night when the dissolve oxygen (DO) level in the ponds drop. Moreover, DO in growout pond is measured using percentage saturation by the farmer every day. When DO level is under $50 \%$ saturation, farmer remove fish into another cage which have good DO level for fish or supply emergency aeration by using extra paddlewheels. This farm have extra generator as a power to prevent unexpectedly case such as lose power in the night that can cause turn off the aeration. According to Glencross and Felsing (2006)[7], larger fish have higher metabolic rate and so that way require more oxygen than smaller fish.

\section{Husbandry and production a) Predators / Disease}

Predation in this farm is not a big issue because there are no report that predation affected profitability and productivity. Big bird like pelicans is the predator for barramundi in this farm. To prevent predation, each cage is covered by oyster tray lid which require $\$ 10,000$ cost per cage. Therefore, approximately 40 tones fish per year for the whole farm can be saved. This cage is also effective to prevent predation like water rat.

The best way to deal with disease is prevention. For nursery, in grading fingerling in GFB Farm, tanks are always cleaned to remove pathogens, and barramundi are put in saltwater bath to kill bacteria before returning to the tank. That activity is conducted once a week. On the other hand, early detection by observing fish feeding behavior is necessary for effective disease management. When some fish not feeding properly from floating pellets, there are some mortality case or they have skin injury, it may be caused by disease. The other method like regularly take some fish from each pond per month is also conducted. Fish that might be has disease is culled and sent to the Queensland Department Industries to be identified or further analyzed. Therefore, to prevent disease spread, antibiotics can be applied immediately into the water or mixed into barramundi feed. Mass mortality in the previous time had been occurred in this farm not because predation or disease but due to mechanic or human error.

\section{b) Feed and feedings}

In GFB farm, feed is the highest cost to run this farm. In the nursery, pellet is given to fish and the pellet size increase depends on the fish size. In the growout, fish are feed by floating pellet and it needs 40-50 tones feed per year for each pond which one ton of feed cost is AUD 1500. Feed diet contains amino acid as stimulate to boast immune system especially in winter. Feed for barramundi is specific and farmer buys feed from Queensland companies particularly from food mill in Brisbane rather than from Tasmania or other part of Australia. It is because transport reason which the farther the distant, the more expensive the cost. The protein percentage in the feed is change depend on fish size. The small fish need higher protein for their growth than the larger fish. In addition, the small fish has better Food Conversion Rate (FCR) which the food is used to increase their body size, while, larger fish for maintain their body mass and metabolic.

Diet composition in barramundi is a prominent factor to achieve better growth. Protein utilization efficiency by barramundi is $46 \%$ and the requirement for protein will decrease with increasing fish size. Moreover, smaller fish has a dietary lipid level of 140-160 g kg-1 and larger fish continued to increase up to $190 \mathrm{~g} \mathrm{~kg}-1$. Barramundi also have limited capacity to utilize dietary carbohydrates for energy, with starch digestibilities below 30\% [8]. According to Harpaz et al (2005) [9], adding salt to barramundi diets has significantly increase the FCR and this might be applied on GFB Farm.

\section{c) Water quality and management}

The water quality is the most important thing to be managed properly in nursery and grow-out. This farm have separate water treatment for grow-out and nursery. For nursery, water flow through long settlement tank and screen for suspended solid and then return to the rearing tank. This farm also applies biofilter to remove and convert ammonium into nitrate. For grow-out, $10 \%$ water flows into shallow settlement ponds that allow UV sunlight to penetrate and sterilize the water. The GFB farm usually does not lime the pond and for storage, water is pumped into header pond.

To maintain water quality, they have checking process to make sure do not have pond problem. They measure water quality such as DO every morning and also take water sample for ammonia, nitrite and nitrate analysis once a month. In addition, they also clean the cage once a month from biofouling or barramundi waste. If there are water quality problems, the farmer usually increase the aeration, improve water exchange, reduce food intake, check biomass in cages and add buffer like carbonic acid to increase alkalinity. By increasing of alkalinity, the phosphorous and $\mathrm{CO} 2$ will available in water 
which can be used for phytoplankton growth. By the increasing of phytoplankton, DO levels will increase in the pond because of phytoplankton photosynthesis [10].

\section{Marketing and profitability}

Fish cycle in grow-out is 86 weeks until they reach $2 \mathrm{~kg}$ before harvesting activity is conducted. GFB Barramundi Farm just sells their product domestically and not import to other country since the price of barramundi from South East Asia such as Indonesia and Vietnam is much cheaper even the quality is lower than Australia product. This is because the labor and production cost in Australia is higher than South East Asia [11]. The GFB Barramundi Farm sold whole fish immediately to suppliers for filleting. Prior to 1993, barramundi in Australia was generally marketed as gutted and gilled. However, today, the greater amount of barramundi is sold live to specific markets, plate size whole fish (350-400 g) and as fillet usually from larger fish of $2.5-3 \mathrm{~kg}$ [12].

\section{CONCLUSIONS}

Barramundi is preferred as a culture species because fingerling production is easy, broodstock can be spawned all year under controlled conditions, and many offsprings are produced each spawning. The number of barramundi farmers has increased which lead to the increasing of barramundi production. However, oversupplied domestic markets would have impact in unprofitable prices for Australian cultured barramundi. In addition, large quantities of cultured barramundi from Asia country that have lower price come to Australian market. Thus, it is prominent that cultured barramundi markets like economic analysis including operating cost, annual return, infrastructure and labor cost to be researched and identified thoroughly before undertaking into barramundi production. The barramundi aquaculture industry in Australia would not have developed without the applied research which is conducted by both private agencies and government.

\section{REFERENCES}

[1] Carter, B. Glencross, R.S. Katersky, M. Bermudes and M. Coregonids, Centropomidae Latidae. In: N.R. Le Francois, M. Jobling, C.G. Carter and P.U. Blier,
Editors, 2009, Diversification of Finfish Aquaculture, CAB International, Wallingford, CT.

[2] ABARE, 2009. Australian fishery statistics 2008, Australian Bureau of Agricultural and Resouce Economics, 81 pp

[3] Tailor made fish farms, 2010, Environmentally Responsible Fish and Vegetable Production Systems, http://www.tailormadefishfarms.com.au/

[4] Barlow, C., 1997. Barramundi, The new rural industries: A handbook for farmers and investors, Rural Industries Research \& Development Corporation, pp. 93-100

[5] Boonyaratpalin,M. and Williams, K., 2002.Asian sea bass, Lates calcarifer. In: Webster, C.D., Lim, C. (Eds.), Nutrient Requirements and Feeding of Finfish for Aquaculture. CAB International, pp. 40-50.

[6] Holm, J.C., Refstie, T, and Siglborn, B. 1990. The effect of fish density and feeding regimes on individual growth rate and mortality in rainbow trout. Aquaculture 89:225-232

[7] Glencross, B.D. and Felsing, M., 2006. Influence of fish size and water temperature on the metabolic demand for oxygen by barramundi, Lates calcarifer (Bloch), in freshwater, Aquaculture Research, 37: 1055-1062

[8] Glencross, B., 2006. The nutritional management of barramundi, Lates calcarifer - a review, Aquaculture Nutrition, 12: 291-309

[9] Harpaz, S, Hakim, T.Y., Slosman, T. and Eroldogan, O.T., 2005. Effects of adding salt to the diet of Asian sea bass Lates calcarifer reared in fresh or salt water recirculating tanks, on growth and brush border enzyme activity, Aquaculture, 248: 315- 324

[10] Lucas, J.S., Southgate, P.C. (Eds.), 2003, Aquaculture farming aquatic animals and plants. Blackwell Publishing, Oxford.

[11] Johnston, W.L., 1998, Commercial barramundi farming estimating profitability. Department of Primary Industries, Brisbane. 